\title{
"Une recherche esthétique autant que morale": Jean Genet's Literary Invasions
}

\section{Tolga AKGUN}

San Francisco State University, San Francisco

French literature's l'enfant terrible, Jean Genet, famously described his literary vocation as follows during an interview: "I couldn't change the world alone, I could only pervert it: this is what I attempted by a corruption of language, that is to say from within this French language that appears so noble." Furthermore, he conceived this corruption as an aesthetic and moral search that was formulated in his novel Journal $d u$ voleur. This article seeks to show how this search for corruption unfolds in Genet's fictions.

I argue that what seems to emerge from this search is an act of literary invasion that Genet highlighted in a conversation with William Burroughs in 1968: "There was the French language and there was me. I put myself inside the other, then the job was done." 2 This act of invasion defined as putting oneself inside the French language operates mainly in three different, and yet connected, sites in Genet's fictions: theft, homosexuality and betrayal/treason. These three sites of invasion, defined as "vertus théologales"3 by Genet, urge us to rethink our relations, as readers and interpreters, to literature itself insofar as they deploy an array of formal and thematic disruptions. While the thematic mode of invasion brings these deviant subject matters into the literature and claims their aesthetic recuperation, very much like in the poetry of Baudelaire, the formal mode subverts conventional aesthetic registers. In this war of 
words, the motif of stealing becomes an act of stealing the words of the enemy to use against him in the same way that betraying France becomes a betrayal through its language. In this article, I will particularly focus on the notions of theft and treason vis-à-vis language, and show that when the language is stolen and/or becomes an object of treason, it can pave the way for aesthetic rehabilitation.

While Genet recounts his personal history to contextualize the moral aspect of his search, he reveals that this aspect is fundamentally based on three "vertus" that he calls "théologales:"4 treason/betrayal, theft and homosexuality. In the original Christian context, faith, hope and charity are the cardinal virtues bestowed upon man by god to bring him closer to divine life. However, Genet is seeking the subversion of these values in the form of treason/betrayal, theft and homosexuality, but the common thread that holds together these values, other than the scorn that they get from the normative morality, is not really clear. Genet's own testimony does not shed much light onto the connections among these virtues either. In his affirmation of having wanted everything that has happened to him, Genet presents himself as a pure product of social misfortune and recovers his freedom in a choice made after that misfortune. However crude this schema may seem, social misfortune remains one of the most determining factors behind his choices. When Madeleine Gobeil asks him in an interview why he "decided" to be a thief, a traitor, and a homosexual, this is the manner in which Genet explains how he negotiated and exercised a certain level of agency in the face of circumstances, for instance, in terms of assuming or "choosing" his homosexuality:

I didn't decide, I didn't make any decision. But there are certain facts. If I started stealing, it's because I was hungry. Later it became necessary for me to justify my act, to absorb it in a sense. As for homosexuality, I have no idea. What do we know about it anyway? Do we know why a man chooses this or that position for making love? Homosexuality was imposed on me like the color of my eyes, the number of my feet. When I was a little kid I became aware of the attraction I felt for other boys; I never experienced an attraction for women. It's only after becoming aware of this attraction that I "decided," that I freely "chose" my homosexuality, in the Sartrian sense. Put another way and more simply, I had to get used to it, while I knew that society disapproved. ${ }^{5}$

Furthermore, concerned with the heroic continuity between his earlier vagabond life and late criminal activities, Genet examines "la 
sorte d'échange vasculaire" that exists "entre [s]on goût pour la trahison, le vol et [s]es amours." Thus, he explores and exploits the literary topos, criminality/ homosexuality, already established with Balzac (the character Vautrin for instance) and Gide (a slew of characters in Les faux-monnayeurs) in French literature. However, his remarks on the correlations that exist between these engagements are strangely offhanded and self-evident: "En effet, mon goût et mon activité de voleur étaient en relation avec mon homosexualité, sortaient d'elle qui déjà me gardait dans une solitude inhabituelle." appeared for the first time in "Les Temps Modernes" as early as in 1946 before its official publication in 1948. One of the passages in these excerpts quickly sketches a reflection on the opposition among these three traits of his personality:

La trahison, le vol et l'homosexualité s'opposent. Par trahison je veux entendre la délation. Ici (en moi) le vol parait symboliser l'activité sociale. La délation me ramène dans la légalité, me relie à la société. L'homosexualité était le lien (le terrain) de choix pour l'apparition du conflit. L'homosexualité refuse et appelle l'illégal, refuse et appelle le social. ${ }^{9}$

As seen in this passage, the words such as "la trahison" or "la délation" connote treason and betrayal for Genet and both of these terms converge with literary engagement as he tells Antoine Bourseiller in an interview: "Ecrire, c'est le dernier recours qu' on a quand on a trahi." ${ }^{10}$ And the reason why betrayal is in opposition to theft is that by becoming a poet, to get out of the prison, Genet betrays, in a way, the (failed) thief that he was. And he also betrays the world of thieves that was his. The beginning of this betrayal was already apparent in the Yugoslavian prison episode in Journal $d u$ voleur_where the narrator was feeling like a stranger among the thieves. After this episode, the betrayal for Genet gains a literary accent: "Il fallait que je trahisse le vol qui est une action singulière au profit d'une opération plus universelle qui est la poésie." "This is how the betrayer becomes a poet and the betrayal poetry. Genet betrays the thieves by becoming a poet, but paradoxically, it was for re-becoming a thief by poetry in the end. The poetic betrayal makes possible the poetic accomplishment of the thief, his self-recreation at a higher level. Poetry becomes the highest level of theft because he steals from France its precious language; and he does it as a traitor to accuse it. By betraying the thieves' world, Genet does not join the enemy's side. On the contrary, he becomes the poet, the real enemy of the society and its morality. The poet inserts into the language of the enemy the foreign language of the thief. From now on, the war against the 
enemy takes place in the language. The loving bond with the language is coupled with the war waged against the enemy in his language: "Avant de dire des choses si singulières, si particulières, je ne pouvais les dire que dans un langage connu de la classe dominante, il fallait que ceux que j'appelle "mes tortionnaires" m'entendent. Donc il fallait les agresser dans leur langage." 12 This is why, after his long vagabondages throughout Europe, Genet always returns to France to "[s'] accuser dans sa langue."13 By deciding to accuse himself in France's language, he finally manages not only to release himself from the accusations that the French society charge him with, but also to accuse France, in his turn, not as a judge but as a traitor-poet.

Genet tells us that the day of Christmas 1939 marks his poetic rebirth. On that day, he decides to send a postcard to a friend in Czechoslovakia. This decision prompts his first poetic emotions as a writer. Touched by the images on the card, instead of wishing his friend a merry Christmas, he describes these images and it all begins like this: "J'ai commencé à écrire à partir de là. Je crois que c'est le déclic. C'est le déclic enregistrable."14 This is also the year France goes to war against Germany, which ends with its occupation- a period riddled with fear, shame and treason. Genet hardly hides his joy before this humiliation of France, as though this latter was finally punished by Germany for the crimes it committed against him: “(...) je ne pouvais qu'adorer celui qui avait mis en œuvre l'humiliation de la France." "In fact this desire for vengeance and treason is the foundation of the poetic adventure in Genet, as Marie Redonnet highlights: "sa vengeance invente une nouvelle loi, qui est celle de la poésie, créatrice d'une trahison supérieure." 16 Ironically, treason and language had already been tied up for Genet since his childhood. When in elementary school in Alligny-en-Morvan, the teacher asks the students to describe their houses in a composition. Having decided that Genet's is the best, he reads it out loud in class. Out of jealousy or childish cruelty, other children make fun of Genet, accuse him of lying for the reason that this house could not exist since he was an orphan in a foster home. In a later interview, this is how Genet remembers his feelings: "Et alors, il y a eu un tel vide, un tel abaissement. J'étais immédiatement tellement étranger, oh! le mot n'est pas fort, haïr la France, c'est rien, il faudrait plus que haïr, plus que vomir la France." "17 These children for Genet represented France. Later in 1949, in his essay "L'Enfant Criminel," he continued to denounce France's crimes not only against him but all abandoned children: "Personne ne s'est avisé que depuis toujours, dans les bagnes d'enfants, dans les prisons de France, des tortionnaires martyrisaient des enfants et des hommes." 18 These are the 
autobiographical foundations of treason, but also of literary vocation, in Genet. By poetically betraying France that betrayed him, he gives voice to these children like himself. His poetry takes, in fact, a higher form of treason. For Genet, France is not only a home from which he is excluded. It is also a language that he is accused of using better than anyone else, as other children told him. And he, indeed, assumes this accusation and the language like his own property. However, through the language that he makes his own, paradoxically, he remains attached to France that excludes him. He never loses his status of enemy or stranger vis

à-vis France, but he never loses his love for this country's language either. So whether he wanted or not, Genet's literary engagement remains indirectly sealed with France by a loving bond; because to glorify French language through a poetry that attacks France is

the scandalous and the paradoxical task that Genet assumes as a poet. And treason is the site of this love-hate relationship that Genet fosters with France and French language. So in the end, the treason of the poet is, actually, also an act of love.

Even though it appears to be a moral treatise at first, Journal du voleur is actually the product of a search for aesthetics. And just as is the case with the moral dimension, the aesthetic dimension of this search also relies on Genet's past life. One of the expressions that Genet uses to bring up his past life is the notion of "matière-prétexte:" raison d'être is precisely that life. By this expression, he also maintains the primacy of the interpretation over the facts, an interpretation "qui sans les détruire en crée de nouveaux. ${ }^{" 20} \mathrm{He}$ indicates that the narration of the episodes since his exit from Mettray comes from an approach that is less retrospective than creative, in other words, poetic. When Genet mentions poetry, he means it literally or etymologically: poet is a creator (with the broad meaning of the word "maker" as in the Latin word "poeta") who works on the shapeless matter with art to give it a form and an order. Similarly, writing, in Journal du voleur, is a way of taking up the unshaped material of the past to give it a form. Writing is a way of engaging the mind with memories, and of molding the lived experience depending on the intention that justifies it. In this regard, Genet mentions that Journal $d u$ voleur is the poem of what he calls "la conscience du vol:" "[...] ce que j'ai recherché surtout, c'est d'être la conscience du vol dont j'écris le poème." ${ }^{21}$ To make poetry out of his life is to refuse the confusion of tangled memories of the past, and to head towards being "la conscience du vol" realized by the poetry: "La poésie consiste dans sa plus grande conscience de sa qualité de voleur." 22 In other words, "la conscience du 
vol" is this transition from chronicle to poetry, or simply the poetry, that expresses in retrospect the innermost reality of an adventure that is less intensely lived at the time. From then on, we see an old practice that is already inaugurated in Genet's earlier fictions Notre-Dame-des-Fleurs and in Miracle de la Rose: recourse to what he calls his "goût profond de l'imposture." ${ }^{23}$ Like many other writers, Genet is displeased to see the expression of a personal truth in a simple narration, or a chronicle, of life experiences. By declaring that "la vérité n'est pas mon fait. Mais 'il faut mentir pour être vrai' Et même aller au-delà,,"24 Genet claims this "imposture" as a creative, and a poetic, method that helps him unify and organize his 1930's according to an ideal (put in perspective in 1940's) that animates and qualifies them: the theft.

For Genet, genesis of the thief also corroborates, then, the signs of a literary vocation as Véronique Bergen underlines: "A l'instar du détournement des objets et du sens de la propriété que Genet opérait par le vol, -détournement de leur usage, de leur destination pratique-, il déviera lạ fonction des mots, étranglera la finalité des choses en les épaississant d'un autre sens, d'une autre valeur, en les transfigurant." ${ }^{25}$ Cocteau explains as well this ethical and aesthetic connection between theft and literature with a paradoxical formula that he calls "mauvais voleur/bon écrivain" in an interview done with André Fraigneau in 1951:

A.F.- Que pensez-vous de l'œuvre de Genet?

J.C.- J'admire en lui un fabuliste. Il fait parler les animaux. Je veux dire les hommes qui n'ont pas de langage, dont les sentiments sont très complexes pour qu'ils puissent s'exprimer.

A.F.- Et son côté voleur?

J.C.- Jean Genet est un mauvais voleur. Le vol est son violon d'Ingrès. Sartre et moi, prétendons que c'est par là qu'il touche à la mode. Notre époque adore les escrocs, les voleurs. C'est le succès de Maurice Sachs. ${ }^{26}$

However, later on, Genet will misinterpret Cocteau's expression "mauvais voleur." The reason is that, for Genet, the word "thief" is a metaphor for the word "poet." So for him, "being a bad thief" is the same as "being a bad poet" since these two converge to the point where the distinction in between becomes undetectable. Similarly, poetry, for Genet, is not just a hobby ("son violon d'Ingrès.") This is how he responds to Cocteau's comment that he calls "une boutade":

Ma stupeur fût grande quand je m'aperçus à quel point le vol était répandu. J'étais plongé au sein de la banalité. Pour en sortir, je n'eus besoin que de me glorifier de mon destin de voleur et 
de le vouloir. C'est là que l'on vit une boutade ${ }^{27}$ dont sourirent les sots. L'on me dit un mauvais voleur ${ }^{28}$ ? Qu'importe. Le mot voleur détermine celui dont l'activité principale est le vol. Le précise en éliminant- pendant qu'il est ainsi nommé- tout ce qu'il est autre que voleur. Le simplifie. La poésie consiste dans sa plus grande conscience de sa qualité de voleur. ${ }^{29}$

There is a misunderstanding between Cocteau and Genet because for the latter, the word "thief" is charged with a poetic connotation ("la poésie" and "sa qualité de voleur.") By poeticizing and aestheticizing, otherwise very common and banal ("répandu" and "banal,") activity of theft, he also glorifies ("glorifier") it, and distinguishes himself as an "artist-thief" from a simple thief whose activity is simply nothing but theft: "Le précise en éliminant [...] tout ce qu'il est autre que voleur. Le simplifie." Instead of eliminating anything other than being a thief, Genet is precisely interested in "tout ce qu'il [le voleur] est," since the poet is a part of this discarded "tout." But Cocteau simply refers to the literal meaning of the word "thief." What Cocteau seems to point out is the fact that Genet, often times, concentrates on the world of objects and the nature as a source of poetry and forgets their utilitarian and practical value, along with the actual undertaking of the activity of theft. ${ }^{30}$ This is what makes him "a bad thief," only on practical grounds, but a good poet on the flip side.

Indeed, crime and writing have always been tightly woven in Genet's life. It is a widely documented fact that Genet started taking an interest into writing and literature by stealing books and discovering their market value. He also spent a lot of time in prisons and penitentiary facilities where he frequented libraries quite often (this is how he discovered Proust, for instance.) Similarly, one of the last essays in Sartre's Saint Genet deals with crime and literature in Genet's life, as the title suggests. Sartre's main idea in this essay is that Genet, basically, substitutes crime with literature: "theft is a criminal act which is de-realized into a dream, whereas a work of art is a dream of murder which is realized by an act." 31 In this compact and circular stream of thoughts, Sartre tells us that crime (in this instance theft) is a dream or a product of imagination that is turned into a work of art that is, in its turn, an act. Crime indirectly becomes an act in writing. The poem of evil action is itself an evil action. So Genet is clear about the distinction between the act and the idea of killing, or art and life: " $D$ 'abord, il ne faut pas confondre les plans: il y a le plan littéraire et il y a le plan vécu. L'idée d'un assassinat peut être belle. L'assassinat réel, c'est autre chose." 32 Through the beauty of his style, "he will make us re-perform spontaneously the free act that makes it possible to reassume the world: 
but the world which is assumed will be that of crime," ${ }^{33}$ as Sartre indicates. Clearly, as opposed to the criminal who kills, Genet is not set out to kill anyone. However, since reading practice goes along with an emotional transference, he knows that his writings on crime can infiltrate a possible reader's mind. His literary object can make the reader imagine the crime. In the same way that the murderers can become an object of public scrutiny and make people read and imagine their crimes described and commented in the newspapers, Genet intends to achieve the same kind of notoriety with his fictions without necessarily becoming a criminal himself. This seems to be the idea that Genet had in his mind when he answered Hubert Fichte's question, "pourquoi vous-même, n'avez-vous jamais commis de meurtre?" in the following way: "probablement parce que j'ai écrit mes livres," during an interview. ${ }^{34}$ Genet stopped engaging into various criminal activities when the petition signed by the intellectuals in 1948, to drop charges against him, got accepted by the president of the republic. But he never stopped committing crime; only this time, it was in literature and, as Sartre puts it, "it [was] with words that Genet [started to lay] his traps" ${ }^{\prime 35}$ to captivate people and to avenge himself at last.

This seems to be the reason why Journal $d u$ voleur associates closely the moral approach with the tone, that is, the effect of language in a literary work of art. Towards the end of the book, before he says goodbye to the reader, he insists one last time on the question of tone:

Mon souci de la cohérence me fait un devoir de poursuivre mon aventure à partir du ton de mon livre. Il aura servi à préciser les indications que me présente le passé: sur la pauvreté et le crime puni j'ai posé le doigt, plus lourdement, et à plusieurs reprises. C'est vers eux que j'irai. ${ }^{36}$

And during the narrative break between the episodes of Spain and Eastern Europe, he announces solemnly:

Ce qui, m'étant un enseignement, me guidera, ce n'est pas ce que j'ai vécu mais le ton ${ }^{37}$ sur lequel je le rapporte. Non les anecdotes mais l'oœuvre d'art. Non ma vie mais son interprétation. C'est ce que $m$ 'offre le langage pour l'évoquer, parler d'elle, la traduire. ${ }^{38}$ In fact, Genet treats the question of tone as a matter of proof. The tone proves the truth of the content matter and it justifies the value of the work of art. The word "preuve" is constantly repeated in the text in conjunction with beauty that is also proved by "le chant." ${ }^{39}$ Likewise, Pierre-Marie Héron sees Genet's aesthetic project based on: "tirer des mots de son français une émotion de lecture capable de prouver la beauté donc de découvrir la vérité." ${ }^{40}$ In Journal $d u$ voleur, aesthetics and morality are 
the two sides of the same medal. Genet lets the reader notice this very early in the text, starting with his first reflection on le chant in conjunction with the moral act:

De la beauté de son expression dépend la beauté d'un acte moral. Dire qu'il est beau décide déjà qu'il le sera. Reste à le prouver. S'en chargent les images, c'est-à-dire les correspondances avec les magnificences du monde physique. ${ }^{41}$

At the same time, these lines emphasize the power of persuasion of the poetic beauty, on those who can feel it. Persuasion is vouched precisely when "le chant" touches the innermost part of the self: the emotion. Poetry, for Genet, is not only consciousness ("la conscience du vol") ${ }^{42}$ but also a new emotion ("émotion nouvelle") ${ }^{43}$ coming from present but also past life experiences; and it is written "selon l'expression d'eux [les émois] imposée par eux [les émois]." 44 Therefore, Genet stays faithful to the classical understanding of poetry as the expression of these emotions experienced by the "I." He implies that "I" is a string of emotions ("un chaplet d'émois,") ${ }^{45}$ hence the connection between le moi and l'émoi. Le chant is, then, the response of the "main à plume"46 to an emotion in a "univers où [le poète se] compla[ît]." ${ }^{47}$ But where is exactly the authority of the poet coming from? It seems difficult to justify the beauty while "singing" about a universe that is not only "réputé vil"48 but also known as criminal. But in Genet's poetic conception, no universe is exluded from beauty, whether that may be social or anti-social. He recognizes in every poet (and he was an avid reader of Baudelaire, Mallarmé, Nerval, Verlaine and Rimbaud) the creator of a world, a style, thus, an autonomous person. According to Marc Dambre, Genet embodies this poetic autonomy and sovereignty: "L'essentielle faculté poétique consiste à nier les valeurs du monde, à contrecarrer ce monde par l'exercice d'une souveraineté révoltée." ${ }^{49}$ Therefore, he insists on the role of lyricism as a self-evident proof of the beauty, and as a manifestation of the sovereignty of the poet:

Tout au plus pourrait-on entreprendre ma rééducation artistiqueau risque toutefois pour l'éducateur, de se laisser convaincre et gagner à ma cause si la beauté est prouvée par, de deux personnalités, la souveraine. ${ }^{50}$

In brief, the beauty of the ignoble comes from and proved by its ability to evoke emotions through le chant.

Indeed, the aesthetics of poetry in Genet's novels are centered on "la réhabilitation de l'ignoble." 51 And it is this attraction to the ignoble and the rage toward the conventional beauty that place Genet in the heart of French literary modernity. As Philippe Lacoue-Labarthe underlines, " $[. .$. 
modern art cultivates what is 'not beautiful,' that is, the simple opposite of the beautiful according to its classical definition: the adequation of form to content." ${ }^{22}$ If we look at this question of adequation between form and content as an equation between the good and the beautiful versus the bad and the ugly, then from this angle, we can say that Genet challenges this adequation and redefines it by putting the beautiful adjacent to the bad. Consider, for instance, the subversion of the registry of aesthetic appreciation in Genet's writings where objects or certain bodily fluids or details that one could find grotesque or macabre (the content) can be given a beautiful aesthetic expression (the form). Realities of the marginal lives such as prostitutes, transvestites, vagabonds and petty criminals are subsumed by art. Genet's short film, Un chant d'amour, shot in 1950 is a prime example of this aesthetic transformation. The movie focuses on the chain of longing desire between two prisoners and a prison guard in a French prison. The younger prisoner dances and walks around in his cell in a narcissistic gesture knowing that the older prisoner is in love with him. The older prisoner dreams about his beloved while touching himself on his bed. Meanwhile, the prison guard takes voyeuristic pleasure in watching them. Seeing that they are sharing a cigarette smoke with a straw inserted through the wall, he gets jealous of their relationship, enters the older prisoner's cell, beats him, and makes him suck on his gun as though they are simulating oral sex. The intensity of the sadomasochistic attraction between these characters is stylized through the use of black and white camera focusing on the close-ups of bodies, faces, armpits and penises. The viewer can easily notice the material depravation that pervades these close-ups, for instance in the prisoners' tattered clothing, dirty toes and fingernails as well as the dilapidated walls and beds. However, these aesthetic details that may be considered vile are integral to this extremely sensual and provocative homoerotic relationship insofar as they are juxtaposed. These aesthetic elements form an imagery that conveys the experience of desire between marginal people such as homosexual convicts.

This collapse of apparent distinction between disgust and desire, good and bad taste is common to Genet and to decadent writers. Genet and his literary ancestors, the decadents such as Baudelaire, investigated our conflicted relation to aesthetics that involves both repugnance and fascination, insofar as this relation tries to reject and eliminate the debasing 'low' and yet stays powerfully attracted by this dark "Other." Similarly, in their thought-provoking book The Politics and Poetics of Transgression, Allon White and Peter Stallybrass go to considerable and convincing lengths to demonstrate that repudiation is crucial for the formation of identity and 
aesthetics in Western culture:

Bourgeois [culture] continuously defined and re-defined itself through the exclusion of what it marked out as "low"- as dirty, repulsive, noisy, and contaminating. Yet that very act of exclusion was constitutive of its identity. The low was internalized under the sign of negation and disgust. But disgust always bears the imprint of desire. (191)

So the aesthetic novelty that Genet, and Baudelaire, bring is the fact that what is excluded at the overt level of normative aesthetics is productive of new objects of desire. In an interview from 1964, for instance, Genet is asked a question having to do with the poetics of his writing that play with this dynamic of disgust/desire. When the interviewer Madeleine Gobeil refers to his definition of poetry (from Pompes Funebres) as "the art of employing shit and getting people to eat it," he replies: " [...] poetry consisted in transforming material and people thought vile into material accepted as noble through the use of language." 53 Clearly, the beauty that Genet celebrates is the opposite of what can traditionally be read in lyric poetry, for instance in the poetry of Ronsard in which, ironically, Genet discovered his first poetic emotions. In fact, the writer celebrates the dregs of society and the sentiments considered "vile" by a "volonté de réhabilitation des êtres, des objets, des sentiments réputés vils." ${ }^{54} \mathrm{I}$ argue that his poetry recuperates the abject experience as an object of aesthetic value. In this regard, Julia Kristeva's reflection on abjection and aesthetics explains well Genet's logic of literary perversion: "The writer fascinated by the abject, imagines its logic, projects himself into it, introjects it, and as a consequence perverts language- style and content." 55

However, poetry for Genet is not just an aesthetic surplus value added to the things and beings to embellish them. Poetry is an action that comes from an act of will to rehabilitate: "La poésie est une vision du monde par un effort, quelquefois épuisant, de la volonté tendue, arc-bouté. La poésie est volontaire. Elle n'est pas un abandon, une entrée libre et gratuite par les sens $[\ldots] "$ ]"56 Within this rehabilitation, he uses literary commonplaces on a thematic and stylistic level to write about marginal figures and their experiences, starting with himself. In an interview in 1982, Genet, to whom Bertrand Poirot-Delpech was asking why he used such a beautiful language to describe the dregs of society, replied: "Ce que j'avais à dire à l'ennemi. Il fallait le dire dans sa langue, pas dans la langue étrangère qu'aurait été l'argot." ${ }^{57}$ Using the enemy's language as a "weapon" against him, but also finding his own, was Genet's literary strategy very much in sync with Baudelaire's famous literary motto, "créer un poncif," 58 which 
consisted in taking a literary commonplace and aesthetically refashioning it. This celebration of the beauty in ugliness was already a prominent theme in Baudelaire's Les Fleurs du Mal in which the poet sang for the dregs of Paris, prostitutes and handicap beggars. And, similarly, this literary strategy was already in place early on in Genet's literary career since one of his first fictions Miracle de la rose: "Dans un poème, les mots habituels sont déplacés et replacés de telle sorte qu'à leur sens courant s'en ajoute un autre: la signification poétique." 59 In both Baudelaire and Genet, there is a desire, by writing, to transfigure the ugliness and to magnify it in its gravity as an alternative against the lure of

the illusion of conventional beauty, as we observe through Genet looking back at the Spanish episode in Journal du voleur: "en refusant la beauté trompeuse de l'Andalousie, je découvrais la poésie." ${ }^{\prime 60}$ This transfiguration is especially noticeable when it operates on the bodies. The deterioration of the body, whether that may be in Baudelaire's "La Charogne" or in Genet's Spanish episode, is turned into a spectacle. Furthermore, the abject body in Genet is very similar to the body of Baudelarian dandy because in both cases, the self is aestheticized through language and body. Or, in other words, the presentation of the body sustains this cult of the self. In Genet, abjection borders on dandyism turned upside down; nevertheless, abjection is still an art form that sustains a certain kind of narcissistic selfinvestment. Only in Genet's version of dandyism, Baudelaire's luxurious fabrics and voluptuous perfumes somehow give way to lice and tattered clothes. Bodily details considered vile are exalted to the point where the religious and cultural construction of the body at the expense of nature is denounced, as Nietzsche elaborates: " [...] the animal 'man' is finally taught to be ashamed of all his instincts [...] sinfulness of the raw material of man, terrible stench, secretion of saliva, urine and excrement."

In the final analysis, Journal du voleur is an act of literary invasion insofar as it represents Genet's effort to carve out a new literary space to speak for marginalized people by aesthetically rehabilitating them. In this regard, theft and treason can be considered as metaphors for the aesthetic re-appropriation of the language necessary for this project of aesthetic rehabilitation. This is the way in which Genet conceives the task of the writer as an ethical and aesthetic project. Ethics and aesthetics, the two modes of invasion, converge in Journal du voleur as the two sides of the same search since they both require a certain kind of discipline and rigor vis-à-vis one another. But we should not think that Genet is the only actor in his poetic enterprise. Ethical and aesthetic exigencies are imposed upon the writer as much as the reader because if Genet treats 
his reader as an enemy, it is for awaking him better: "Je voudrais bien m'affranchir des morales conventionnelles, celles qui se sont cristallisées et qui empêchent l'épanouissement, qui empêchent la vie. Mais un artiste n'est jamais complètement destructeur. Le souci même de faire une phrase harmonieuse suppose une morale, c'est-à-dire un rapport de l'auteur à un lecteur possible." 62 This relational morality presupposes the idea of ethical and aesthetic responsibility to give voice to those who are silenced in society. Ethics of poetry in Genet hinges upon this responsibility of the poet to rehabilitate; and it is this kind of responsibility that makes necessary the literary invasion.

\section{Notes}

1. The Declared Enemy, 56.

2. Quoted by Edmund White in Genet: A Biography, 510.

3. Journal du voleur, 167.

4. Ibid.

5. The Declared Enemy, 3.

6. Journal du voleur, 193.

7. Ibid.

8. Ibid., 277.

9. “Journal du voleur." Les Temps Modernes July 1946: 39-40. Print.

10. L'Ennemi déclaré, 225.

11. Ibid., 15.

12. Ibid., 230 .

13. Journal du voleur, 121.

14. L'Ennemi déclaré, 165.

15. Ibid., 149.

16. Jean Genet, le poète travesti, 25.

17. L'Ennemi déclaré, 149.

18. "L'Enfant Criminel," 389.

19. Journal du voleur, 132.

20. Ibid.

21. Ibid., 105.

22. Ibid., 277.

23. Notre-Dame-des-Fleurs, 253. Miracle de la Rose, 294.

24. Notre-Dame-des-Fleurs, 244.

25. Jean Genet- Entre mythe et réalité, 225.

26. Entretiens autour du cinématographe, 35. 
27. My italics.

28. My italics.

29. Journal du voleur, 277.

30. For further information on the phenomenology of theft, see Michael Hardt. "Prison Time." Yale French Studies 91 (1997): 64-80.

31. "On the Fine Arts Considered as Murder." Saint Genet, 485.

32. L'Ennemi déclaré, 112.

33. Saint Genet, 497.

34. L'Ennemi déclaré, 113.

35. Saint Genet, 491.

36. Journal du voleur, 305.

37. My italics.

38. Journal du voleur, 232-233.

39. "Le but de ce récit, c'est d'embellir mes aventures révolues, c'est-à-dire obtenir d'elles la beauté [...] le chant, seule preuve de cette beauté" (Ibid., 230.); "L'acte est beau s'il provoque, et dans notre gorge fait découvrir, le chant" (Ibid., 23-24).

40. "Lucien la nuit," 103.

41. Journal du voleur, 23-24.

42. Ibid., 105.

43. Ibid., 132.

44. Ibid., 193.

45. Ibid., 132.

46. Ibid., 9

47. Ibid.

48. Ibid., 122.

49. "Notre-Dame-des-Fleurs récit de poète vide enfance," 39.

50. Journal du voleur, 218.

51. Ibid., 26.

52. Poetry As Experience, 91.

53. The Declared Enemy, 7-8.

54. Journal du voleur, 122.

55. Powers of Horror. An essay on abjection, 16.

56. Notre-Dame-des-Fleurs, 260.

57. L'Ennemi déclaré, 234.

58. "Fusées," 79.

59. Miracle de la rose, 233.

60. Journal du voleur, 84.

61. On the Genealogy of Morality, 47.

62. L'Ennemi déclaré, 16. 


\section{Bibliography:}

Baudelaire, Charles. Fusées. Mon cœur mis à nu. La Belgique déshabillée. Paris: Gallimard Folio, 1986. Print.

Bergen,Véronique. Jean Genet- Entre mythe et réalité. Bruxelles: De Boeck Université, 1993. Print.

Cocteau, Jean. Entretiens autour du cinématographe. Paris: André Bonne, 1951. Print.

Dambre, Marc. "Notre-Dame-des-Fleurs récit de poète vide enfance."

Roman 20-50: Revue d'étude du roman du XX $X^{e}$ siècle 20 (1995):

27-43. Print.

Genet, Jean. Journal du voleur. Paris: Gallimard Folio, 2007. Print.

-- Notre-Dame-des-Fleurs. Paris: Gallimard Folio, 2003. Print.

--- Miracle de la Rose. Paris: Gallimard Folio, 2005. Print.

-- Querelle de Brest. Paris: Gallimard L'Imaginaire, 1986. Print.

--- "L'Enfant Criminel." CEuvres complètes V. Paris: Gallimard, 1979. Print.

--- L'Ennemi déclaré. Textes et entretiens choisis 1970-1983. Ed. Albert Dichy. Paris: Gallimard Folio, 2010. Print.

--- The Declared Enemy. Texts and Interviews. Ed. Albert Dichy. Trans.

Jeff Fort. Stanford: Stanford University Press, 2004. Print.

-.- "Journal du voleur." Les Temps Modernes July 1946: 49-50. Print.

Héron, Pierre-Marie. "Lucien la nuit." Roman 20-50: Revue d'étude du roman du XXe siècle 20 (1995): 93-105. Print.

Kristeva, Julia. Powers of Horror. An essay on abjection. Trans. Leon S.

Roudiez. New York: Columbia University Press, 1982. Print.

Lacoue-Labarthe, Philippe. Poetry As Experience. Stanford: Stanford University Press, 1999. Print.

Nietzsche, Friedrich. On the Genealogy of Morality. Ed. Keith Ansell-

Pearson. Trans. Carol Diethe. Cambridge: Cambridge University

Press, 2004. Print.

Redonnet, Marie. Jean Genet, le poète travesti. Portrait d'une œuvre.

Paris: Grasset, 2000. Print.

Sartre, Jean-Paul. Saint Genet. Actor and Martyr. Trans. Bernard Frechtman. New York: Pantheon Books, 1963. Print.

Stallybrass, Peter. White, Allon. The Politics and Poetics of Transgression. Ithaca: Cornell University Press, 1995. Print.

White, Edmund. Genet: A Biography. New York: Vintage Press, 1994. Print. 